INTERNATIONAL JOURNAL OF

SYSTEMATIC BACTERIOLOGY

Vol. 16, No. 2

April 1966

pp. $151-160$

\title{
COMPARISON OF THE CHEMICAL COMPOSITION OF CELL-WALLS OF NOCARDIAE WITH THAT OF OTHER AEROBIC ACTINOMYCETES
}

\author{
Hubert Lechevalier, Mary P. Lechevalier and \\ Benjamin Becker
}

Institute of Microbiology, Rutgers, The State University New Brunswick, New Jersey

\begin{abstract}
Analyses of cell-wall preparations from more than 230 aerobic actinomycetes representing most of the morphologicaltypes among those forming well developed mycelia (euactinomycetes) reveal that cell-wall preparations from allactinomycetes containglucosamine, muramic acid, glutamic acid, and alanine as major constituents. In addition, the broad group of the streptomycetes, including the pathogenic s. somaliensis, contain major amounts of glycine and L-diaminopimelic acid. Preparations from micromonosporae contain glycine and meso-diaminopimelic acid and those from members of the family Actinoplanaceae contain meso-diaminopimelic acid with or without glycine. Preparations from strains of Dermatophilus, Thermoactinomyces, Microbispora and nocardiae of the madurae-pelletieri type contain meso-diaminopimelic acid. Preparations from strains of Thermomonospora, Micropolyspora, Pseudonocardia and nocardiae of the farcinica-asteroides type contain mesodiaminopimelic acid, arabinose and galactose. The genus Nocardia is not considered homogeneous with respect to the cell-wall composition of its members. Furtherstudies will undoubtedly show the value of splitting that genus into two groups, but this must await the development of simple and reliable methods for differentiation.
\end{abstract}


Recent studies of the cell-wall composition of actinomycetes, largely the work of Cummins and his collaborators, have revealed that anaerobic or microaerophilic actinomycetes (members of the genus Actinomyces) differ sharply in cell-wall composition from aerobic actinomycetes (Cummins, 1962). The anaerobic forms contain lysine either alone or with ornithine (Cummins, 1965)

as major cell-wall constituents, whereas the aerobic forms contain 2,6-diaminopimelic acid. In addition, among the aerobic actinomycetes, there were organisms with at least two different types of cell walls; those containing only the meso form of 2,6-diaminopimelic acid and those containing the L-isomer of this acid either alone or in combination with some meso (or/and D-) form. Cummins observed that most strains he received as belonging to the genus Nocardia contained, as major cell-wall constituents, meso-diaminopimelic acid, arabinose and galactose. He also stressed that most strains received as belonging to the genus Streptomyces contained, as major cell-wall constituents, L-diaminopimelic acid and usually did not contain any sugars.

Inspired by the results of Cummins, we started a survey of the chemical composition of cell-wall preparations of as many morphologically different aerobic actinomycetes as we could handle. We soon came to realize that the presence of major amounts of L-diaminopimelic acid in the cell walls of aerobic actinomycetes was almost always found only in preparations made from streptomycetes. Since most of the diaminopimelic acid is found only in the cell wall, the detection of the presence of this acid and its isomeric form does not require the preparation of isolated cell-wall fractions. This led us to propose a simple differentiation method between Nocardia and Streptomyces by paper chromatography of whole-cell hydrolysates (Becker et al. 1964). Of course, one cannot make a sure generic diagnosis on the basis of this single criterion, but it is most useful in the separation of atypical streptomycetes from atypical nocardiae.

Recently Yamaguchi (1965) and my colleagues and I (Becker et al. 1965) have shown that one could separate aerobic actinomycetes into four groups on the basis of the major constituents present in their cell walls. Yamaguchi's conclusions were based on the analyses of cell-wall preparations of 30 strains of actinomycetes; ours were based on similar analyses of more than 140 strains. In Table I are listed the most important genera of aerobic actinomycetes 
Table I

Major constituents present in cell wall preparations of aerobic actinomycetes

All preparations contained major amounts of glucosamine, muramic acid, alanine and glutamic acid.

DAP $=2,6$-diaminopimelic acid

\begin{tabular}{|c|c|c|c|c|c|c|}
\hline $\begin{array}{l}\text { Cell wall } \\
\text { type }\end{array}$ & Principal genera & glycine & $\stackrel{\text { L-DAP }}{=}$ & meso-DAP & arabinose & galactose \\
\hline I & $\frac{\text { Streptomyces }}{\text { Microëllobosporia }}$ & $t$ & $t$ & & & \\
\hline II & Actinoplanes & + & & + & & \\
\hline III & $\begin{array}{l}\text { Thermoactinomyces } \\
\text { Microbispora } \\
\text { Dermatophilus }\end{array}$ & & & $t$ & & \\
\hline IV & $\begin{array}{l}\frac{\text { Nocardia }}{\text { Micropolyspora }} \\
\frac{\text { Thermomonospora }}{\text { Mycobacterium }}\end{array}$ & & & + & + & + \\
\hline
\end{tabular}


together with the major chemical constituents found in cellwall preparations made from representative strains. One will note in the table that some genera are listed at the interface between two groups. These include: 1) the genus Micromonospora because cell walls of a few of its members contain a small amount of L-diaminopimelic acid in addition to major amounts of meso-diaminopimelic acid, 2) the genus Streptosporangium because some of its members contain some glycine in addition to meso-diaminopimelic acid, and 3) Nocardia because some of the organisms now called Nocardia contain major amounts of a rabinose and galactose, in addition to meso-diaminopimelic acid, and others do not.

On the basis of a study of the morphology of actinomycetes that has lasted for more than a decade and on the basis of the chemical composition of the cell-wall preparations of more than 150 strains of aerobic actinomycetes, we have proposed (Lechevalier and Lechevalier, 1965) a system of classification of aerobic actinomycetes according to which these organisms were grouped into five families:

Dermatophilaceae (Austwick, 1958),

Actinoplanaceae (Couch, 1955),

Streptomycetaceae (Waksman and Henrici, 1943, emend.) Micromonosporaceae (Krasil'nikov, 1941),

Nocardiaceae (Lechevalier and Lechevalier, 1965).

The family name Nocardiaceae was mentioned by Bisset and Davis in 1960 but, according to a private communication from Bisset, the name of this taxon was never validly published by these authors.

In Tables II, III and IV are listed the organisms that we have studied and that we would place, at least tentatively, in the genera Nocardia and Micropolyspora. In Table II, we find organisms that have been identified as either Nocardia madurae or Nocardia pelletieri by Dr. F. Mariat of the Pasteur Institute of Paris or by Dr. Ruth E. Gordon. None of the $\mathbf{N}$. pelletieri strains ever sporulated in our hands. Some strains of $\underline{N}$. madurae sporulated and when they did, they formed short chains of conidia on the aerial mycelium only. Table II also includes some organisms that we isolated from soil that sporulate like strains of $\mathrm{N}$. madurae. Two of these strains were identified as $N$. madurae by R. E. Gordon.

In Table III we find organisms that were identified by Mariat as either Nocardia farcinica or $N$. asteroides together with those strains identified by Ruth E. Gordon as $\underline{N}$. asteroides and $\underline{N}$. brasiliensis. In addition, we have included organisms that did not sporulate either as N. 


\section{Table II}

Cell-wall composition of strains of Nocardia of the madurae-pelletieri type

Unless otherwise indicated the cell-wall preparations from these organisms were of type III (see Table I).

Organisms

Nocardia madurae RG-431; RG-507; RG-746-M ${ }^{f}$;

RG-948g, k; RG-953f; RG-959a,b, c,f,j; RG-1091;

RG-1136; RG-1234; RG-1253b; RG-N1070;

IMRU-3632A ${ }^{\text {b }}$ LL-Sal. 1; LL-P56; RG-1190; RG-95fgj; RG-94igk; RG-746f

Nocardia pelletieri RG-408; RG-408W; RG-513

RG-514g; RG-610; RG-677g; RG-687g; RG-741g;

$\mathrm{M}-755^{\mathrm{a}}, \mathrm{b} ; \mathrm{RG}-756 \mathrm{~g} ; \mathrm{RG}-778^{\mathrm{a}}, \mathrm{b}, \mathrm{c}, \mathrm{f}$

Nocardia flexuosa $\mathrm{K}-1132^{\mathrm{e}, \mathrm{i}}$

Nocardia sp. RG-717; LI-37-46g; LL-P13 ${ }^{\text {h }}$ : LL-I3

LL-W $45^{\mathrm{d}}, \mathrm{i}, j$; LL-W234; LL-I19h, LL-I2 $2^{\mathrm{g}}$, LL-K18

${ }^{a}$ Contains also minor amounts of glycine.

${ }^{b}$ Contains also minor amounts of aspartic acid.

c Contains also minor amounts of serine.

dContains also major amounts of ornithine.

eontains also minor amounts of galactosamine.

${ }^{f}$ Contains also minor amounts of glucose.

gContains also major amounts of glucose.

${ }^{h}$ Contains also minor amounts of mannose.

${ }^{i}$ Contains also major amounts of mannose.

jContains also minor amounts of galactose.

${ }^{k}$ Contains also major amounts of galactose.

$M=$ from F. Mariat, Pasteur Institute, Paris.

$K=$ from N. A. Krassilnikov, Academy of Sciences, Moscow.

RG = from Ruth E. Gordon, Rutgers University •

$L I=$ Author's collection.

IMRU = Institute of Microbiology, Rutgers University. 


\section{Table III}

Cell-wall composition of strains of Nocardia

of the farcinica-asteroides type

Unless otherwise indicated the cell-wall preparations from these organisms were of type IV (see Table I).

\section{Organisms}

Nocardia farcinica $M-1223^{\mathrm{a}} ; \mathrm{M}-1225 ; \mathrm{RG}-1242 ; \mathrm{RG}-1243$ M-1224

Nocardia asteroides LL- $102^{\mathrm{b}, \mathrm{i}}$; LL-5000S; LL-5000F;

RG-A5 ; RG-SL 107B; RG-539; RG-856; RG-857 ${ }^{\text {; }}$

RG-E9991; RG-782

Nocardia brasiliensis IMRU-3487 ${ }^{i}$ RG-774A; RG-7748 ${ }^{i}$

Nocardia caviae RG-424; RG-732; RG-1233; RG-N1934 ${ }^{\mathrm{a}, \mathrm{b}}$; RG-1252

Nocardia vaccini IMRU $-3500^{\mathrm{a}, \mathrm{b}}$

Nocardia sp. RG-1105a, c, g, j; RG-1124a, c,e,f,j; LL-B4a; IMRU-3520c,e, h,j; LL-SS $1 / 1^{b}$, d LL-L18 $8^{c}$ LL-P52

${ }^{2}$ Contains also minor amounts of glycine.

${ }^{b}$ Contains also minor amounts of aspartic acid.

c Contains also major amounts of aspartic acid.

dContains also minor amounts of galactosamine.

econtains also minor amounts of glucose.

fContains also minor amounts of rhamnose.

gContains also minor amounts of mannose.

${ }^{h}$ Contains also major amounts of mannose.

iContains no galactose.

jPreviously referred to, by error, as N. coeliaca.

$M=$ from F. Mariat, Pasteur Institute, Paris.

RG = from Ruth E. Gordon, Rutgers University .

$L L=$ Author's collection.

IMRU = Institute of Microbiology, Rutgers University. 
Table IV

Cell-wall composition of strains of Micropolyspora

Unless otherwise indicated the cell-wall preparations from these organisms were of type IV (see Table I).

\section{Organisms}

Micropolyspora brevicatena LL-1084; LL- 1086

Micropolyspora rectivirgula K-1325

Micropolyspora sp. G-A91; G-A92; G-A94; LL-1085;

LL-37-2; LL-37-20; LL-37-25; LL-P30; LL-P78A;

LL-P78/50-2; LL-S22; LL-S29; LL-S96; LL-W-4,

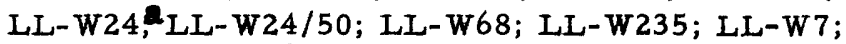

LL-27-12; LL-K17; LL-W 14

${ }^{a}$ Contains also minor amounts of rhamnose.

${ }^{\mathrm{b}}$ Contains also minor amounts of ribose.

$\mathrm{LL}=$ Author's collection .

$\mathrm{K}=$ from N. A. Krassilnikov, Academy of Sciences, Moscow.

$G=$ from P. H. Gregory, Rothamsted Experimental Station, Harpenden, Herts, England. 
madurae does (short chains of conidia on the aerial mycelium only) or as micropolysporae do (short chains of conidia on both the substrate and the aerial mycelia) that had a cell wall of type IV. These included strains of $\underline{N}$. caviae and $\underline{N}$. vaccini.

In Table IV are listed the organisms that sporulated as previously described (Lechevalier et al. 1961) with the formation of easily detectable short chains of conidia on both substrate and aerial mycelia. Krasil'nikov and Agre (1964) expressed the opinion that there was no need to separate organisms forming short chains of conidia on the aerial mycelium only from those forming the same structures also on the substrate mycelium. On the contrary, our studies lend support to the value of such a separation. Not only do we find a difference in cell-wall composition between the two sporulating types (Tables II and IV), but whatever information we have been able to obtain by time-lapse photography indicates that the conidia of micropolysporae are formed by a process of elongation and walling off of the sporophores, whereas strains of the $\underline{N}$. madurae type formed conidia, as streptomycetes do, by the simultaneous division of preexisting aerial hyphae (arthrospores). Some strains of streptomycetes and of $\underline{N}$. asteroides also form chains of conidia on the substrate mycelium. These are usually not easily seen and we know nothing as yet about their mode of formation.

One will note that cell-wall preparations made from micropolysporae are identical in chemical composition to those of the nocardiae of the farcinica-asteroides type. One could thus say that micropolysporae are the members of the broad group of the nocardiaceae with the most elaborate sporife rous system. One will also note that one cannot differentiate, on the basis of cell-wall composition, a strain of Micropolyspora that would have lost the ability to sporulate from a strain of Nocardia farcinica or $\mathrm{N}$. asteroides. Furthermore, as pointed out by Cummins (196 $\overline{2}$ ), one cannot, on the basis of cell-wall composition, separate these organisms from mycobacteria.

Gordon and Mihm (1962) have proposed that $\underline{N}$. asteroides be considered the type species of the genus Nocardia. This proposal was made in the absence of newly isolated strains of $N$. farcinica and as a consequence of finding that old stock strains of $N$. farcinica we re identical with strains of $N$. asteroides and with the belief that Nocard's description, as cited by Trevisan, applied to a strain of $N$. asteroides. 
Among these old strains of $N$. farcinica was ATCC 3318 which, according to Dr. Waksman's records, was Nocard's original strain. The isolation from cases of farcy in Africa of N. farcinica strains (studied by Mariat) has given us reliable biological material for our analyses. On the basis of these cell-wall preparation analyses we could not find any difference between strains identified as $N$. farcinica and those identified as $\underline{N}$. asteroides. One should note, however, that strains of $N$. farcinica were much harder to grow than strains of $\underline{N}$. asteroides. It is thus possible that $\underline{N}$. farcinica might be a more parasitic form of $\underline{N}$. asteroides.

The cell-wall preparations are long and tedious to make even though their analyses are often of great diagnostic value. It is our aim to try to develop additional simple tests to help in the identification of aerobic actinomycetes. We hope to achieve some success in this field by the development of chemical tests carried out on hydrolysates of whole cells.

\section{Acknowledgments}

The authors wish to thank all those who have contributed strains as indicated in the tables. The technical assistance of Mrs. Clara Trummer is gratefully acknowledged. This work was supported by Public Health Service grant AI 05489.

\section{LITERATURE CITED}

Austwick, P.K. C. 1958. Cutaneous streptothricosis, mycotic dermatitis and strawberry foot rot and the genus Dermatophilus Van Saceghem. Vet. Rev. Annotations $\underline{4}: 33-48$.

Becker, B., M. P. Lechevalier, R. E. Gordon and H. A. Lechevalier. 1964. Rapid differentiation between Nocardia and Streptomyces by paper chromatography of whole-cell hydrolysates. Appl. Microbiol. 12:421-423. and H. A. Lechevalier. 1965. Chemical composition of cell-wall preparations from strains of various form-genera of aerobic actinomycetes. Appl. Microbiol. $13: 236-243$.

Bisset, K. A. and G.H. G. Davis. 1960. The microbial flora of the mouth. Heywood and Co., Lts., London.

Couch, J. N. 1955. Actinosporangiaceae should be Actinoplanàceae. Jour. Elisha Mitchel Sci. Soc. 71:269. 
Cummins, C.S. 1962. La composition chimique des parois cellulaires d'actinomycetes et son application taxonomique. Ann. Inst. Pasteur 103:385-391. - 1965. Ornithine in mucopeptide of Gram-positive cell walls. Nature 206:1272.

Gordon, R.E. and J.M. Mihm. 1962. The type species of the genus Nocardia. Jour. Gen. Microbiol. 27:1-10.

Krasil'nikov, N. 1941. Guide to Actinomycetales (in Russian). Moscow.

and N.S. Agre. 1964. On two new species of Thermopolyspora. Hindustan Antibiotics Bull. 6:97-107.

Lechevalier, H. and M. P. Lechevalier. 1965. Classification des actinomycètes aérobies basée sur leur morphologie et leur composition chimique. Ann. Inst. Pasteur 108:662-673.

, M. Solotorovsky and C.I. McDurmont. 1961. A new genus of the actinomycetales: Micropolyspora gen. nov. Jour. Gen. Microbiol. 26:11-18.

Waksman, S. A. and A. T. Henrici. 1943. The nomenclature and classification of the actinomycetales. Jour. Bact. 46:337-341.

Yamaguchi, T. 1965. Comparison of the cell-wall composition of morphologically distinct actinomycetes. Jour. Bact. 89:444-453. 